Оригинални научни рад

Amarilla Kiss, Lecturer

Institute of International Studies and Political Science

Pazmany Peter Catholic University

kiss.amarilla@btk.ppke.hu

\title{
PROBLEMS OF THE INVESTIGATION AND PROSECUTION IN CASE OF PIRACY AT SEA
}

Abstract: Sea piracy became a current topic around 2008 when the number of attacks increased in the Gulf of Aden. However it is more or less repressed by now, piracy has a unique shifting nature: it decreases in one region, but it increases in another, therefore it is always present to some extent. Besides, Somali piracy was the first that made international community take steps and these strategies and programmes serve as an important lesson that can be partly adaptable in other cases as well. It reveals important questions around enforcement jurisdiction and the most exciting problem: prosecutions. This paper attempts to briefly take a glance at those difficulties that can set back the success of a piracy prosecution and if there is a progress. First, it presents the root-cause: jurisdiction. National laws regulate piracy in a very different way or they don't criminalize them at all and this can lead to serious consequences. In the following chapter the process of investigation is presented. Collecting evidence is incredibly difficult in case of piracy and if it fails, prosecutions fail too. In the end the paper attempts to focus on the trial and what follows: costs of prosecutions, asylum-seekers, human rights considerations and prison facilities.

Key words: sea piracy, prosecution, law enforcement, non-refoulement, investigation

\section{Introduction}

Piracy is a crime which violates international law and over which any state may exercise its national jurisdiction. It continues to be a threat to international shipping mainly because of the prosecutions have usually failed and so it means that it is a collective problem for the international community. The main reason is the lack of uniformity in the regulation referring to piracy that can end in controversial or directly opposite decisions. There have been several different ideas 
about prosecuting pirates in front of international or at least partly international courts, but the reality is that these cases and the perpetrators usually end up in front of a national court. Some years ago 'catch and release' was a typical strategy as nobody really wanted to prosecute pirates, but by now it is not that huge problem than it used to be, though, in this case, the increasing number of prosecution poses new challenges to states.

The aim of this paper is to briefly present the obstacles and hardships that shall be taken into account when prosecuting the offenders of this crime. In the second chapter I present the basic jurisdictional dilemmas, especially the unique character of this crime from the aspect of enforcement jurisdiction, therefore we can understand why it is so important to emphasize the prosecution of pirates. Then, in the following chapter, the investigation is in focus as it is the key element to successful proceedings. The last chapter analyzes the problems around the trial: the question of transfer, the costs, the human rights aspects and how the pirates serve the punishment.

\section{Dilemmas of jurisdiction}

When one tries to discover what obstacles are in the way of a successful prosecution, the problem of jurisdiction is the first to begin with.

According to the 1982 United Nations Convention on the Law of Sea (UNCLOS), the prosecution of the suspects is not an obligation, but the Convention for the Suppression of Unlawful Acts against the Safety of Maritime Navigation (SUA Convention) requires from the state parties to take steps and try these people. ${ }^{1}$

Though it is not the aim of this paper to discuss the definition, but it must be mentioned that the problem starts here as there is a difference between piracy and armed robbery at sea. This paper deals with the first one mainly as the second one is more difficult to define in a standard way that most of the nations accept and in case of functioning states it is even more difficult to apply these rules. I don't attempt to define or deal with the sensitive issue of maritime terrorism on highs seas which is also very complicated to separate from traditional piracy as the definition and the regulation referring to terrorism itself are very complex and have a delicate nature.

However, the question arises, who can prosecute pirates? Since we know that states can regulate this question within their national laws which can lead to differences and it also happens that states don't criminalize piracy at all, instead they rely on the definition provided by the UNCLOS. ${ }^{2}$ Therefore, to start, it

\footnotetext{
${ }^{1}$ Article 105 of the UNCLOS, Article 3 of the SUA Convention

${ }^{2}$ E.g. the United Kingdom
} 
must be examined if piracy is an international crime or not as it seems to be a well-known fact that it is an international crime and the only one that traditionally invokes universal jurisdiction. It prima facie seems to be an easy question to answer, we have the Article 101 of the $\mathrm{UNCLOS}^{3}$ that defines this crime, but if we look at the previous documents, the travaux preparatoires on which the UNCLOS is based, it doesn't seem to be that obvious anymore. The Harvard Draft Convention, which is the basic document, expressly states that if an incident of piracy happens, it is the domestic law which prosecutes the perpetrators. ${ }^{4}$ If we look at the piracy regulation of the $\mathrm{UNCLOS}^{5}$, it has that specific nature that is very common in public international law, the lex imperfecta, so that it defines piracy and the conduct that constitutes it, we have the hypothesis and the disposition but we lack the sanction. ${ }^{6}$ The aim of the rules is to help us navigate among jurisdictional principles as this is a special crime where states exercise extraterritorial jurisdiction.

So we can conclude that piracy is not an international crime (like genocide for example), but rather a crime that violates international law. Therefore states are in charge of prosecuting the perpetrators based on municipal law, so they can regulate this crime in different ways, which has its own risks as they can extend this definition (referring originally only to high seas) to their own territorial waters as well like Japan or Kenya. ${ }^{7}$ Unfortunately this invokes another problem, namely that most of the judges have never faced the prosecution of this crime before. In order to evade this problem special piracy chambers started to operate in regional states that apply their domestic law. So prosecutions must happen based on national laws, but are national laws able to handle the prosecutions? The typical cases cited here are the Ahmed and Hashi cases. ${ }^{8}$ In the two similar cases the Kenyan court reached opposite conclusions in connection with

\footnotetext{
3 'Piracy consists of any of the following acts: 61 (a) any illegal acts of violence or detention, or any act of depredation, committed for private ends by the crew or the passengers of a private ship or a private aircraft, and directed: (i) on the high seas, against another ship or aircraft, or against persons or property on board such ship or aircraft; (ii) against a ship, aircraft, persons or property in a place outside the jurisdiction of any State; (b) any act of voluntary participation in the operation of a ship or of an aircraft with knowledge of facts making it a pirate ship or aircraft; (c) any act of inciting or of intentionally facilitating an act described in subparagraph (a) or (b).'

${ }^{4}$ Harvard Draft Convention on Piracy, Art. 14(2), Robin Gei $\beta$, Anna Petrig, Piracy and Armed Robbery at Sea, Oxford University Press, 2011, p. 231.

${ }^{5}$ Mainly Art. 100-111 of UNCLOS

${ }^{6}$ Gei $\beta$, Petrig, p. 141 .

${ }^{7}$ Alice Priddy, Stuart Casey-Maslen, Counterpiracy under International Law, Academy Briefing No.1., Geneva Academy of International Humanitarian Law and Human Rights, August 2012, p.43.

${ }^{8}$ Jessica Piquet, 'Changing Tides: An adaptable Prosecution Approach to Piracy's Shifting Problem', Columbia Journal of Transnational Law, Vol. 52, No. 1, 2014, p. 252.
} 
its jurisdiction. The same situation happened in the United States v. Said and the United States v. Hasan cases, but not with regard to jurisdiction, but the court examined whether the certain conduct of the suspects could constitute piracy or not. ${ }^{9}$ So there can be different outcomes even within one state that leads to controversy and raises the question of fairness.

\section{Technical Problems of Investigation}

Besides the above-mentioned jurisdictional dilemmas, investigation is a very important contributing factor to a successful law enforcement. Searching aboard, collecting evidence and getting the necessary information from witnesses and victims are key elements of this process in order to prosecute perpetrators effectively. ${ }^{10}$ By having the evidence, we are provided information about the weapons and capacity perpetrators have which could lead to successful prevention and self-defence. ${ }^{11}$ However, gathering evidence on sea under such extraordinary circumstances is complicated, therefore it is essential to reveal the difficulties of this process.

In their study Henri Fouche and Jacques Meyer ran a survey by asking participants of the investigation in order to discover the main issues investigators face when they have to collect physical evidence ${ }^{12}$. They found that because of the special circumstances the problems start as early as they visit the crime scene, it is not easy to get aboard with a team of investigators not to mention their equipment which can be used only in a limited way ${ }^{13}$, so they must consider well what to take with themselves on board as nothing is easy to access from a vessel and even if they could, there is a limited space to apply these tools, so they must plan every step beforehand ${ }^{14}$.

Apart from the technical problems, we must take human factors into consideration: after an attack, the crew usually continues shipping until the next port,

\footnotetext{
${ }^{9}$ Maggie Gardner, Piracy Prosecutions in National Courts, Journal of International Criminal Justice, Vol.10, Issue 4, 2012, p. 800.

${ }^{10}$ PB Weston, CA Lushbaugh, Criminal investigation: basic perspectives, Pearson/Prentice Hall, Upper Saddle River, 2006 cited in Henri Fouche, Jacques Meyer, 'Investigating sea piracy: crime scene challenges', in WMU Journal of Maritime Affairs, Vol.11, issue 1, 2012

${ }^{11}$ E.g. Petros Liacouras, 'Intelligence Gathering on the High Seas', in Unresolved Issues and New Challenges to the Law of the Sea, Publications on Ocean Development, Vol.54, eds. A. Strati, Maria Gavouneli \& N. Skourtos, M. Nijhoff Publishers, Leiden, 2006, p. 126.

${ }^{12}$ Henri Fouche, Jacques Meyer, 'Investigating sea piracy: crime scene challenges', in WMU Journal of Maritime Affairs, Vol.11, issue 1, 2012

${ }^{13}$ Ibid. p.45. E.g. the author mentions that investigators cannot use high capacity cameras because of safety reasons.

${ }^{14}$ Ibid. p.44.
} 
so they can't be interrogated at once ${ }^{15}$. On the one hand, when it happens to interrogate them, ${ }^{16}$ the witnesses (and many times they are the victims at the same time) must stay on board until investigators finish with interviews, which is very stressful for them, especially if they can't make themselves understood because of the language difficulties or, on the other hand, it is also possible that they finished the service and there is a new crew on the vessel and in this latter case it is difficult to reach all of them as the crew member often have different nationality. ${ }^{17}$ Piracy is a type of crime where the crew could be held hostage even for months which means that usually the crime scene is already contaminated by the time investigators arrive.

Since on the vessel there is not much space, evidence can be damaged during investigation and there are additional factors contributing to the loss of evidence, these are due to weather conditions (e.g. humidity or the strong wind) or the special location (a vessel is always rolling). ${ }^{18}$

Besides, problems around jurisdiction and difficulties in administration can also have a negative effect on investigation. When a piracy incident happens, different actors are involved: first of all, the crew and those (usually military forces) who were the fastest to arrive at the scene, then policemen, inspectors, the owners of the ship, the security company and the prosecutors. It is easy to conclude that timing and acting fast are key issues when investigating, but since there are so many participants who would like to react quickly, there is often a serious misunderstanding of competence among them which also sets back the investigation. ${ }^{19}$

States realized that this procedure required so much effort, that the international community ${ }^{20}$ recognized the need for transnational co-operation and tried to specify the methods of evidence gathering and relied on INTERPOL as a coordinating link among national police, military forces and other judicial elements in charge of prosecution. This was an important action since in theory the

\footnotetext{
${ }^{15}$ Priddy, Casey-Maslen, p.45.

16 Tatjana Bugarski,'Ispitivanje svedoka', Zbornik radova Pravnog fakulteta u Novom Sa$d u, 4 / 2013$, p. 131-143.

${ }^{17}$ Ibid. p.45.

${ }^{18}$ Ibid. p.43.

${ }^{19}$ Ibid. p.46.

${ }^{20}$ 2010/766/CFSP EU Council Decision amending Joint Action 2008/851/CFSP on a European Union military operation to contribute to the deterrence, prevention and repression of acts of piracy and armed robbery off the Somali coast http://eur-lex.europa.eu/LexUriServ/LexUriServ.do?uri=OJ:L:2010:327:0049:0050:EN:PDF (accessed 3 March 2015)

Though this decision refers to the specific case of Somalia, the international circulation of data and the coordinating role of INTERPOL are important in overall piracy cases, even in case of those of armed robbery committed in zones controlled by functioning states.

Not only the EU, but the Security Council also agreed on the role of INTERPOL in S/RES/1950 (2010) and S/RES/ 1976 (2011)
} 
INTERPOL already had the authorization to deal with this crime ${ }^{21}$, but until Somali piracy and armed robbery emerged, there had been no need for any concrete action. The same applies to the regulation of the SUA convention which also emphasizes the importance of assistance in case of investigations ${ }^{22}$. So far the IMO has dealt with the question in detail ${ }^{23}$ since it defines who investigators are and gives best practices about the special training of investigators: not only because of the special scene, but also how to handle exhausted and stressed people in order to interview them. ${ }^{24}$ However -similarly to a Security Council resolution $^{25}$ - it does not forget about the fact that the offenders, those who plan, organize, finance or facilitate piracy operations are usually land-based and could be involved in smuggling and trafficking as well. However, the most serious problem is in functioning states where piracy, armed robbery and the above-mentioned land-based crimes go hand in hand, but it is not an investigation strategy question, it is more about a consent among states and the task to settle the problematic jurisdictional questions. Nonetheless, the IMO Code attempts to create cooperation among the affected states ${ }^{26}$, contains the responsibilities of those arriving first at the scene ${ }^{27}$ and contains very detailed information ${ }^{28}$ how to conduct the interviews with witnesses. It calls the attention of investigators to be very careful since the legal norms concerning the prosecution could be different than the rules of that state where the investigators are from and sometimes even years can pass by until it is possible to hold a trial so the evidence must be in satisfactory condition for a long time.

The INTERPOL also provides help in form of equipment and training specialized in evidence collecting on high seas ${ }^{29}$. They also seem to get closer to resolve the problem that it has been almost impossible to catch the real leaders who work and finance piracy from behind. The Global Database run by the IN-

${ }^{21}$ For the first time the INTERPOL had this authorization in the mid 80 's and mainly in connection with terrorism.

${ }^{22}$ 'States Parties shall afford one another the greatest measure of assistance in connection with criminal proceedings... including assistance in obtaining evidence at their disposal necessary for the proceedings.' Protocol of 2005 to the Convention for The Suppression of Unlawful Acts of Violence Against the Safety of Maritime Navigation (SUA convention, adopted 14 October 2005), Article 11 which replaced the original Article 12 of the SUA convention

${ }^{23}$ Code of Practice for the Investigation of Crimes of Piracy and Armed Robbery against Ships (adopted on 2 December 2009), Resolution A.1025(26) (hereafter: IMO Code of Practice)

${ }^{24}$ Ibid. p.6.

${ }^{25}$ UNSC Res 2020 (22 November 2011), UN Doc S/RES/2020

${ }^{26}$ IMO Code of Practice 5.7, p.7.

${ }^{27}$ E.g. preservation of life, prevention of the escape of the offenders, warning to other ships, protection of crime scenes and securing evidence, ibid. pp.6-7.

${ }^{28}$ Ibid. p.9.

$29 \mathrm{http} / / / \mathrm{www}$. interpol.int/Crime-areas/Maritime-piracy/Maritime-piracy (accessed in 5 March 2015) 
TERPOL and supported mainly by the EU NAVFOR, the US Navy and the Seychelles is an important step on this road.

Though international organizations are fairly new subjects to public international law, by now they have a decisive role in international relations. The INTERPOL has also realized it and in order to investigate these crimes more effectively, it started to cooperate with many organizations and it also supports cross-sector partnerships (with NGOs and companies)..$^{30}$

Not only the INTERPOL but also the United Nations Office on Drugs and Crime (UNODC) helps states with special mobile kits for investigations, for example it supported the Seychelles with a major pack which is important as it has contributed to successful trials held in Spain, the Netherlands, Belgium, Germany and in the United States by delivering the necessary evidence. It is also very important that now there exists a database of fingerprints for in some of the cases the prosecution was based only on this evidence and it could be proven that these people were the perpetrators in previous cases. ${ }^{31}$

However, we must note that there are different databases and information centres working in Asia too (Singapore, Malaysia) the only consideration is that 'the usage of private databases has to be compatible with the laws governing the investigation ${ }^{32}$

In conclusion, there are promising initiatives based on the international cooperation, but it would be important to involve shipping industry even more ${ }^{33}$ and to improve communication not only at an international level, but also among the direct actors like inspectors, coastguards, naval authorities and all actors participating in law enforcement.

\section{The Difficulties Affecting the Trial}

In order to try the suspects they need to be transferred to the state where they will be prosecuted and it is possible by means of transfer agreements. These agreements are usually concluded by states involved in an incident and that are part of a counter-piracy programme and those regional states that may not be directly involved, but criminalize piracy in the domestic law and also undertake the task to prosecute pirates. In return the different international organizations and their programmes can support capacity-building financially in the region.

\footnotetext{
${ }^{30}$ E.g. United Nations, European Union, African Union but it also works together with the International Maritime Organization or Eurojust.

http://www.interpol.int/Crime-areas/Maritime-piracy/Maritime-piracy

${ }^{31}$ Priddy, Casey-Maslen, p.45.

${ }^{32}$ IMO Code of Practice, p. 10.

${ }^{33}$ Fouche, Meyer, p.48.
} 
The European Union and its EUNAVFOR has an agreement with Kenya and some states signed a Memorandum of Understanding (MOU) with regional states. Obviously, it is a beneficial and practical solution since this is a serious logistical challenge for many states, not to mention the jurisdictional issues, besides, these prosecutions are expensive and so these states can evade the question of asylum seekers. ${ }^{34}$

However, the regulation of the agreements assures human rights of the suspected to be respected and as we will see in the following, this is a problematic issue.

Basically there are two types of states: regional countries prosecuting pirates mainly upon transfer agreements (e.g. Kenya, Mauritius, the Seychelles, Tanzania) and those states involved in an incident directly (e.g. the Netherlands, Belgium, Denmark, Germany, France, Spain, the USA, Malaysia, India, Japan, the Republic of Korea) that initiate these, but occasionally they prosecute pirates themselves and, as a unique category, we have Somalia itself (Puntland or Somaliland). In chapter II it was mentioned that some states involved in piracy incidents don't have any (more specific) regulation than the one contained in the UNCLOS, so there are serious technical issues, not to mention that even if it is regulated in the national law, the judges are not trained for the unique characteristics of these cases and they lack the experience since many of the judges rarely meet these crimes during his career and at least never on a daily basis. It is also an important motivation for the latter category of states to sign transfer agreements or MOU.

As it was mentioned above, usually these prosecutions mean a considerable financial burden on states, one of the reasons is because piracy is a crime which is committed in an organized form by a group of people, so there are always more than one suspected (usually around 10) and most of the cases could be decided only upon the statements of victims. Therefore the perpetrators, victims, witnesses and evidence must be moved to the location of trial which has its own costs. ${ }^{35}$ It also means that it is almost impossible to find evidence if it was in the criminal stage of suspicion, just before attempting the crime.

These people often don't have any documentation that can prove their identity or age, which causes serious setback and judges have to be especially careful when they prosecute underage people.

It must be also mentioned that the basic human rights of these people must be respected, therefore they have the right for a fair trial ${ }^{36}$, including that they

${ }^{34}$ Priddy, Casey-Maslen, p.44.

${ }^{35}$ Ibid.

${ }^{36}$ Including the basic principles of the presumption of being innocent, to be prosecuted in a reasonable time by impartial judges, right to appeal etc. 
must be provided with legal aid and translation or language they can understand and this is also expensive.

As a matter of fact, the most relevant and questionable issue about human rights is in connection with detention and the transfer. In December 2014, in the case of Ali Samatar v. France, ${ }^{37}$ the European Court of Human Rights (ECHR) held that France had to pay a compensation to Somali pirates because France violated their rights to freedom and security. The incidents happened in 2008 when the pirates hijacked two ships and the French military captured them. They were detained in custody for 4 and 6 days before the trial could start in France so they weren't tried in 48 hours. Regulation like this exist in the national law of other states as well, for example in Germany the following day after the arrest, the suspects must be tried. It can be easily concluded that it is technically impossible to keep these deadlines and the decision of the ECHR can lead to a controversial situation. There has always been an uncertainty because of the lack of capacity, the absence of certain criminal norms, the unclarified jurisdiction and logistical problems that made the period of detention longer and because of this it usually happened that those who captured pirates released them. This tendency has seemed to stop, but the decision of the ECHR doesn't support this trend.

As it was mentioned earlier, many states (especially in Europe and the United States) find it uncomfortable to face the issue of asylum seekers. Whether we examine the situation of pirates from the aspect of refugee law or from international human rights law, we find a common ground: the principle of nonrefoulement. The point of the principle is that it prohibits the removal of individuals to a state where there is a real risk of being exposed to torture, cruel or inhuman treatment, so where his certain human rights could be violated. However, this is just a broad description since this principle can be interpreted in more ways depending on the certain area.

According to refugee law, the basic document is the 1951 Refugee Convention sets the well-known definition of refugee ${ }^{38}$ and defines non-refoulement: "No Contracting State shall expel or return (refouler) a refugee in any manner whatsoever to the frontiers of territories where his right to life or freedom would be threatened on account of his race, religion, nationality, membership of a particular social group or political opinion'.

The question is whether states should apply this principle to pirates. The answer seems to be 'no', for the pirates cannot be regarded as refugees, they don't leave their home country because of a 'well-founded' fear, but in order to

${ }^{37}$ See Affaire Ali Samatar et Autres c. France, no 17110/10 and 17110/10 (ECtHR, 4 December 2014)

${ }^{38}$ Article 1 and Article 1 of the 1967 Protocol Relating to the Status of Refugees 
commit a crime, which is the other reason why they can't be considered as refugees. So can we assure that the content of non-refoulement doesn't apply to them as their life is not threatened there because of reason mentioned in the definition.

If we take international human rights law into consideration, we can rely on the 1984 UN Convention against Torture (CAT) which declares in its Art. 3. that '(1) No State Party shall expel, return or extradite a person to another State where there are substantial grounds for believing that he would be in danger of being subjected to torture. (2.) For the purpose of determining whether there are such grounds, the competent authorities shall take into account all relevant considerations including, where applicable, the existence in the State concerned of a consistent pattern of gross, flagrant or mass violations of human rights.'

This article sets a regulation applicable to everybody, no matter if they are not refugees in the previous sense or if they committed a crime, so it can be applied in case of pirates ${ }^{39}$.

The other basic document used in this field is the 1966 International Covenant on Civil and Political Rights it contains the prohibition of torture ${ }^{40}$ : 'No one shall be subjected to torture or to cruel, inhuman or degrading treatment or punishment... .' This is explained more broadly in the General Comments:' 9. In the view of the Committee, States parties must not expose individuals to the danger of torture or cruel, inhuman or degrading treatment or punishment upon return to another country by way of their extradition, expulsion or refoulement. States parties should indicate in their reports what measures they have adopted to that end. ${ }^{.41}$

The third international treaty that non-refoulement is relied on from the aspect of human rights is the 1950 Convention on Human Rights, its Article 3 is about the prohibition of torture, that is, just like in the previous case, applies to everybody and contains not only torture but inhuman and degrading treatment or punishment.

The third aspect of human rights that is also in connection with non-refoulement and transfer. When the UK for example signed MOUs with the Seychelles (2010), Tanzania (2012) and Mauritius (2012) ${ }^{42}$, the UK set that no convicted pirate can face death penalty ${ }^{43}$ and the same happened when the EU signed the transfer agreement with Kenya. This can be also derived from the

\footnotetext{
${ }^{39}$ Priddy, Casey-Maslen p. 50., Gei $\beta$, Petrig, p. 210.

${ }^{40}$ Article 7

${ }^{41}$ General comment No. 20: Article 7 (Prohibition of torture, or other cruel, inhuman or degrading treatment or punishment), Forty-fourth session, 1992, HRI/GEN/1/Rev.9 (Vol. I) p. 200.

${ }_{42} \mathrm{https} / /$ www.gov.uk/government/news/uk-signs-agreement-with-mauritius-to-transfer-suspected-pirates-for-prosecution (accessed: February 2015)

${ }^{43}$ Priddy, Casey- Maslen p. 49.
} 
International Covenant on Civil and Political Rights as its article 6 contains the right to life $^{44}$ and the general opinion is that those states that don't apply death penalty mustn't transfer or extradite a person to a state where there is a real risk to face such a penalty. ${ }^{45}$ Agreements generally contain these diplomatic assurances not only in case of death penalty but states would also like to evade that pirates would be exposed to inhuman treatment or torture, but there are several signs that states sometimes don't regard it binding, so they don't necessarily mean real protection, though in connection with death penalty it is kept. ${ }^{46}$ Though it is an interesting fact that the expected sentence of pirates captured by France and transferred to the Seychelles increases from an average sentence of seven years in French courts, to nearly 15 in the Seychelles. In case of the U.S. transferring pirates to Kenya, it decreases from life in prison to roughly nine years ${ }^{47}$

Even though piracy causes serious damage and financial loss, because of all the above-mentioned, there is still no public interest which negatively affects the success of trials.

In order to examine what happens after the trial and how the judgements are enforced in reality, it is worth taking a look at the cases of Somali piracy since these judgements are available and their afterlife can also be followed up, so these could show us important lessons to be learnt.

The convicted people guilty of piracy sometimes get a long punishment that must be served in prison. The sentence could be served in different states depending on who captured them, which state they were transferred into and where the trial was held, however most of the prosecutions took place in Somalia and Kenya, so they have a significant experience in the imprisonment of the perpetrators. Besides, Mauritius, the Seychelles and Tanzania have relevant role in prosecution but it is based on the same scheme in all of the above-mentioned states. Nowadays, as the Gulf of Guinea became the centre of piracy attacks it is worth observing the Kenyan examples for the situation in e.g. prison conditions, capacity building, legal clinics, the training of judges and prison officials are basically the same. However these prosecutions clearly have advantages and can serve as a model to learn or benefit from, these don't mean a solution for piracy in other regions. ${ }^{48}$

\footnotetext{
${ }^{44}$ Sanja Đajić, 'Pravo na život: pitanja i odgovori međunarodnog prava', Zbornik radova Pravnog fakulteta u Novom Sadu, 2/2004, pp.461-483.

${ }^{45}$ Gei $\beta$, Petrig, p. 215.

${ }^{46}$ Ibid. p. 218.

${ }^{47}$ Eugene Kontorvich, The Penalties for Piracy: An Empirical Study of National Prosecution of International Crime, Northwestern University School of Law, Faculty Working Papers, 2012, p. 5 .

${ }^{48}$ Piquet, p. 240.
} 
The basic problem was with prison facilities ${ }^{49}$ and although by the support of UNODC and the EU, it was possible to build new blocks to increase the capacity of prisons, yet the tension remained. From a legal aspect, the prison has several functions, but not only restrictive ones like detaining somebody, but also leading perpetrators back to society and normal life, where it is possible, in some cases it's obviously not an option.

Since piracy must be treated in an integrated way, it was great idea to provide different facilities for convicted people (e.g. physical activities, teaching them basic language or mathematic skills ${ }^{50}$ ) and so the state can increase the rate of employment as they need workers for this capacity-building.

If there is a problematic point of this, then we must mention that prisoners usually serve their sentence in a prison especially built for pirates and referring to what is mentioned above, these are rather new, often built by Western European standards, providing more facilities, so they are not really like average prisons in the region. The aim is rehabilitation so they can get basic education etc. The problem is that other criminals serve under very bad circumstances. From European aspect these old prisons are considered to be inhuman, but this is due to the economic situation and what increases this tension is that even the guards work in worse environment and sometimes they even live without modern taps and clear water or electricity.

Nonetheless, the regional prosecution seems to be the most effective and many states and international organizations support states like Kenya, we mustn't forget that if there are only certain states prosecuting pirates it can lead to an overburden of the judicial system ${ }^{51}$ no matter the financial support or the training facilities.

\section{Conclusions}

As we could see there are several setbacks in the way of a successful trial that don't make it easy for judges to decide upon piracy cases. These obstacles are partly legal difficulties and partly due to certain political considerations.

In this paper I attempted to summarize briefly what the necessary components to a prosperous piracy prosecution are as setting the jurisdiction, this is where it all starts, then the fair trial and in order to achieve this, the efficient investigation and evidence gathering and we must also take care about what happens after the trial and how the pirates serve their punishment.

\footnotetext{
${ }^{49}$ E.g. the Seychelles doesn't have many prisons, so those who are prosecuted here are usually transferred to Somalia to serve their sentence in prison.

${ }^{50}$ The report has shown that prisoners were very cooperative, attended at classes and had appreciated the education they got. UNODC Counter Piracy Programme, Issue Eleven, March 2013, p.19.

${ }^{51}$ Piquet, p. 251.
} 
It is a multisectoral answer what is needed to piracy, to improve communication among these sectors and involve shipping industry more in the proceedings.

The international organizations support this process financially and in the form of special trainings and databases which is very useful to eliminate this crime, however the basic reason must be settled and these are the lack of good governance and poverty.

Though the case of Somalia is very exceptional, it is the first time the international community seriously attempted to take actions. This is important as piracy is an ever shifting crime: if it decreases somewhere, it increases somewhere else, it is always present, so it would be very important to implement these strategies in different regions with regard to the specific characteristics of that region as obviously different solutions are needed in case of Asia or in the Gulf of Guinea. However this is a common ground and many lessons learnt in connection with Somalia could be adaptable. 
Амарила Ким, предавач

Католички универзитет „Pazmany Peter“

Институт за међународне студије и политичке науке

\section{Проблеми спровођења истраге и кривичног гоњења у случају пиратерије на мору}

Сажетак: Пиратерија на мору је постала актуелна тема 2008. године када се број напада повећао у Аденском заливу. Међутим, иако је до сада више или мање сузбијена, пиратерија има јединствену природу: она се смағује у једном региону, али се повећава у другом и стога је увек присутна у одређеној мери. Поред тога, пиратерија у Сомалији је била прва која је навела међународну заједнииу да предузме одређене кораке и те стратегије и програми служе као важна лекиија која може бити делимично применљива и у другим случајевима. Она открива важна питања у погледу спровођења надлежности и у погледу решавања најзначајнијег проблема: кривичног гоњења. Овај рад настоји да се укратко осврне на те тешкоће које могу да умање успех кривичног гоњења пиратерије, уколико и постоји одређени напредак. Прво, он представља основни узрок: надлежност. Национални прописи регулишу пиратерију на различите начине, или је уопште ни не криминализују, ито може имати озбиљне последице. У наредном поглављу, приказан је поступак спровођења истраге. Прикупљање доказа је изузетно тешко у случају пиратерије и уколико буде неуспешно, кривично гоњење ће такође бити неуспешно. На крају, у раду је обрађено суђене и оно што следи после ьега: трошкови поступка, тражиочи азила, разматрања о људским правима и затворским објектима.

Кључне речи: пиратерија на мору, кривично гоњење, спровођење закона, забрана враћања лиц̧а (non-refoulement), истрага.

Датум пријема рада: 19.05.2015. 